\title{
Heat-shock induces rapid resorption of primary cilia
}

\author{
CL Thompson ${ }^{1,2^{*}}$, NV Prodromou², DP Osborn ${ }^{3}$, R Ashworth ${ }^{1}$, MM Knight ${ }^{1}$, PL Beales ${ }^{3}$, JP Chapple $^{2}$ \\ From First International Cilia in Development and Disease Scientific Conference (2012) \\ London, UK. 16-18 May 2012
}

Primary cilia are involved in important developmental and disease pathways, such as the regulation of neurogenesis and tumorigenesis. They function as sensory antennae and are essential in the regulation of key extracellular signalling systems. In this study we investigate the effects of cell stress on primary cilia. Exposure of mammalian cells in vitro, and zebrafish cells in vivo, to elevated temperature resulted in the rapid loss of cilia by resorption. In mammalian cells cilia loss correlated with a reduction in ligand dependent hedgehog signalling. Heat shock dependent loss of cilia was decreased in cells where histone deacetylases (HDACs) were inhibited, suggesting resorption is mediated by HDAC6 which localises to ciliary axonemes. The rate of cilia resorption was reduced in thermotolerant cells. This implies a role for molecular chaperones in primary cilia maintenance. The cytosolic chaperone Hsp90 localised to the ciliary axoneme and its inhibition resulted in cilia loss. In the cytoplasm of unstressed cells Hsp90 is known to exist in a complex with HDAC6. Immediately after heat shock Hsp90 levels were reduced in remaining ciliary axonemes. We hypothesise that cilia resorption in response to heat shock is regulated by the disassembly of an HDAC6/Hsp90 complex and would serve to attenuate cilia mediated signalling pathways and reduce the translational load on the cell in times of stress.

\section{Author details}

${ }_{1}^{1}$ Queen Mary University of London, UK. ${ }^{2}$ Barts and the London School of Medicine and Dentistry, UK. ${ }^{3}$ UCL Institute of Child Health, UK.

Published: 16 November 2012
doi:10.1186/2046-2530-1-S1-P52

Cite this article as: Thompson et al:: Heat-shock induces rapid resorption of primary cilia. Cilia 2012 1(Suppl 1):P52.

* Correspondence: c.l.thompson@qmul.ac.uk

'Queen Mary University of London, UK

Full list of author information is available at the end of the article

Submit your next manuscript to BioMed Central and take full advantage of:

- Convenient online submission

- Thorough peer review

- No space constraints or color figure charges

- Immediate publication on acceptance

- Inclusion in PubMed, CAS, Scopus and Google Scholar

- Research which is freely available for redistribution
C Biomed Central 